\title{
Glycosynapses: microdomains controlling carbohydrate-dependent cell adhesion and signaling
}

\author{
SENITIROH HAKOMORI \\ Pacific Northwest Research Institute, 720 Broadway, Seattle, WA 98122-4302 U.S.A. and \\ Departments of Pathobiology and Microbiology, University of Washington, Seattle, WA 98195 U.S.A. \\ Manuscript received on April $1^{\text {st }}$, 2004; accepted for publication on April $2^{\text {nd }}, 2004$; \\ presented by Lucia Mendonça Previato
}

\begin{abstract}
The concept of microdomains in plasma membranes was developed over two decades, following observation of polarity of membrane based on clustering of specific membrane components. Microdomains involved in carbohydrate-dependent cell adhesion with concurrent signal transduction that affect cellular phenotype are termed "glycosynapse". Three types of glycosynapse have been distinguished: "type 1', having glycosphingolipid associated with signal transducers (small G-proteins, cSrc, Src family kinases) and proteolipids; ' type 2" having O-linked mucin-type glycoprotein associated with Src family kinases; and "type 3' having $\mathrm{N}$-linked integrin receptor complexed with tetraspanin and ganglioside. Different cell types are characterized by presence of specific types of glycosynapse or their combinations, whose adhesion induces signal transduction to either facilitate or inhibit signaling. E.g., signaling through type 3 glycosynapse inhibits cell motility and differentiation. Glycosynapses are distinct from classically-known microdomains termed "caveolae", "caveolar membrane", or more recently "lipid raft", which are not involved in carbohydrate-dependent cell adhesion. Type 1 and type 3 glycosynapses are resistant to cholesterol-binding reagents, whereas structure and function of "caveolar membrane" or "lipid raft" are disrupted by these reagents. Various data indicate a functional role of glycosynapses during differentiation, development, and oncogenic transformation.
\end{abstract}

Key words: clustering, carbohydrate-to-carbohydrate interaction, carbohydrate-binding protein, integrin, tetraspanin, growth factor receptor.

\section{INTRODUCTION AND HISTORICAL RETROSPECTIVE}

The concept of microdomains in plasma membrane evolved from questions about the original "fluid mosaic" model of Singer and Nicolson (1972), in which membrane proteins are randomly distributed in the "sea" of homogeneous lipid bilayer. I.e., (i) whether the lipid bilayer is really homogeneous; (ii) whether distribution of membrane proteins is really random.

The “"plate model', proposed by M.K. Jain and E-mail: hakomori@u.washington.edu
H.B. White (Jain and White 1977), which emphasized that the "biomembrane continuum is broken up into a number of relative rigid plates or patches which are in relative motion with respect to each other' may be the first alternative to the Singer and Nicolson model, addressing the above questions. According to this model, the ordered and rigid regions are separated from each other by fluid and disordered regions. Structural and functional units play a role in transport and cellular interaction, and show cooperativity among themselves in order to maintain overall function of biological membranes. 
The Jain/White plate model is illustrated in Fig. 1. This view was remarkably similar to the concept of microdomains elaborated recently [e.g., by D.A. Brown (Schroeder et al. 1994, Arreaza et al. 1994, Brown and London 1997)]. The idea of signal transduction through membrane microdomains was developed only when growth factor receptor tyrosine kinase was shown to be inhibited by surrounding gangliosides (Bremer et al. 1984), and when Src family kinase activity was found to be associated with GPI-anchored receptors (Stefanova et al. 1991) (see Fig. 2 and its legend).

Development of the microdomain concept, initiated by observation of (i) apical vs. basolateral difference in glycosphingolipid (GSL) and glycoprotein (GP) distribution patterns; (ii) clustering patterns of GSLs and GPs; and (iii) functional organization of clustered GSLs or GPs with cytoplasmic signal transducers, etc., is chronologically illustrated in Fig. 2 and its legend.

The concept of microdomains mediating cell adhesion, particularly carbohydrate-dependent adhesion coupled with signaling, was developed only recently, and was termed "glycosynapse" (see below) (Iwabuchi et al. 1998a, b, Hakomori et al. 1998, Hakomori 2000).

\section{GLYCOSYNAPSES: MICRODOMAINS INVOLVED IN CARBOHYDRATE-DEPENDENT ADHESION COUPLED WITH SIGNAL TRANSDUCTION}

Specific carbohydrate epitopes present in cell surface glycoconjugates, either GSLs or N- or O-linked glycoproteins, are recognized by carbohydratebinding proteins or complementary carbohydrates. In each case, glycosyl epitopes, carried by GSLs or glycoproteins, are clustered to form microdomains, in which specific signal transducers, adhesion receptors, or growth factor receptors are organized. Through this organization, carbohydrate-dependent adhesion creates signals that are transmitted to the nucleus, leading to changes in cellular phenotype associated with cell adhesion.

Microdomains involved in carbohydrate-dependent adhesion coupled with signal transduction were termed "glycosynapses" (Hakomori 2002, Hakomori and Handa 2002), in analogy to "immunological synapses" involved in immunocyte adhesion with concurrent signaling leading to activation of T-cells and B-cells (Bromley et al. 2001, Krummel and Davis 2002). The term "glycosynapse" is used to emphasize the point that the terms "caveolae" or "lipid raft" do not indicate cell adhesion, or signaling induced by cell adhesion. This conceptual distinction is illustrated in Fig. 3.

During the early 1990s, the concept of a membrane morphological unit termed "caveolae", characterized by presence of the scaffold protein caveolin and involved in signal transduction and endocytosis/exocytosis, received much attention (for review see Anderson 1998). Membrane microdomains with similar biochemical properties and cell biological functions, but lacking caveolin (Parton and Simons 1995), were frequently observed, to which the term "raft" or "lipid raft" was applied (for review see Simons and Ikonen 1997). Neither microdomain "caveolae" nor "raft" dealt with the essential function of cell adhesion, particularly carbohydrate-dependent adhesion. Furthermore, function of glycosynapse 1 and 3 (see below) is unaffected by or resistant to cholesterol-binding reagents, in contrast to function and structure of "caveolae" and "raft". Contrasting properties of these microdomains are summarized in Fig. 4.

Three types of glycosynapse are described in the following subsections.

\section{I Glycosynapse 1: GSL Microdomains CON- TROLLING GSL-DEPENDENT ADHESION AND SIGNALING}

GSLs have strong ability to interact with each other (cis interaction) through hydrogen bonds, since GSL molecules have both hydrogen bond acceptors and donors. In contrast, glycerophospholipids have no hydroxyl group (i.e., no hydrogen bond donor), and therefore no ability to undergo cis interaction through hydrogen bonds (Fig. 5A). Under scanning EM with freeze-fracture technique, GSL clusters can be clearly seen on cell membranes as well 

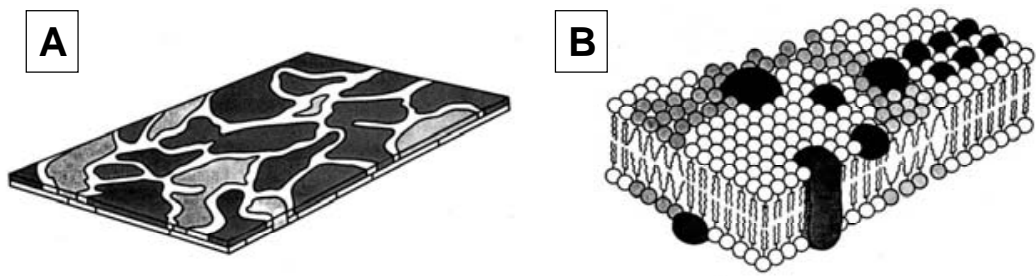

Fig. 1 - Membrane "plate" model proposed by Jain \& White. Panel A: Membrane plate consists of ordered (black) and disordered (gray) lipid areas, each having characteristic properties specified by their components. Panel B: Realistic organization of lipid bilayer, showing presence of "ordered" (white circles) or "disordered" (gray circles) lipids. Note that "ordered" lipids have parallel, hydrophobic tails, whereas tails of "disordered" lipids are at an angle (Y-shape) because fatty acyl residues are unsaturated (contain olefinic double bond).

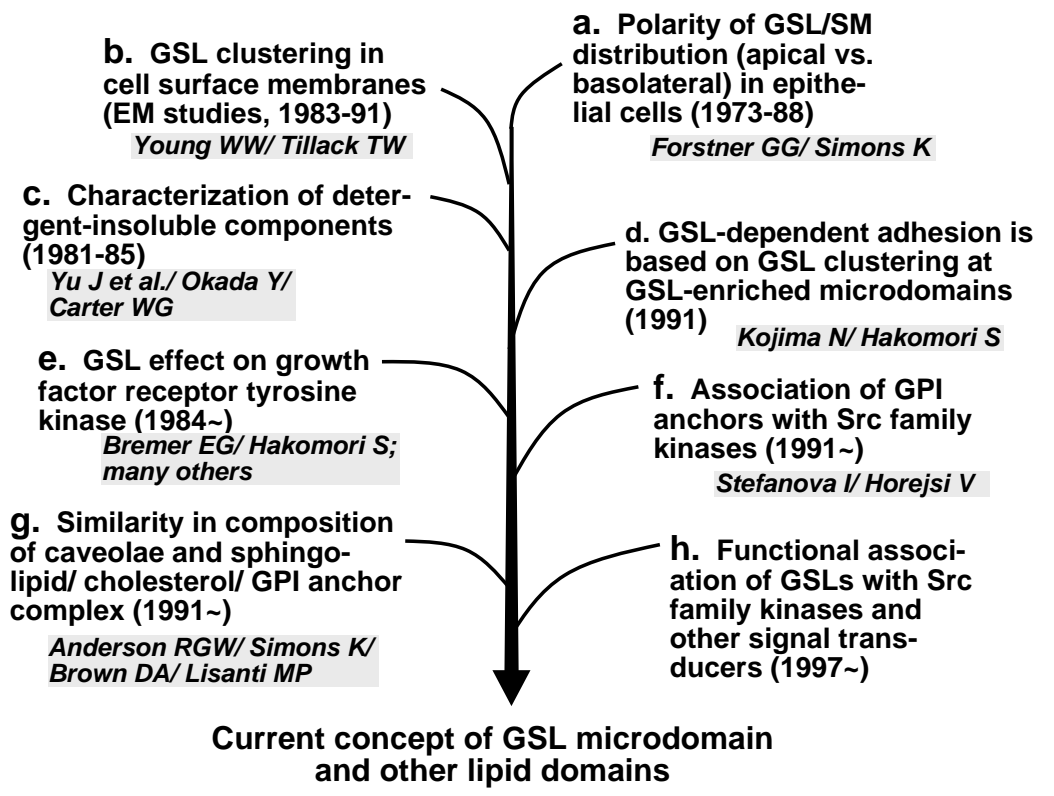

Fig. 2 - Crucial observations leading to the current concept of microdomains. The concept of microdomains, i.e., presence of distinctive composition in different areas of plasma membrane, arose from several lines of study. a. Polarity of GSL/sphingomyelin or glycoprotein distribution in epithelial cell plasma membrane. Forstner et al. observed that brush border membrane in intestinal epithelial cell had distinctively high content of fucose-containing GSL as compared to basolateral area (Forstner et al. 1968, Forstner and Wherrett 1973). Simons et al., using dog kidney epithelial cells (MDCK cells), found distinctive distribution pattern of glycoprotein (Matlin and Simons 1984) and GSL (Hansson et al. 1986) in apical vs. basolateral membrane. b. GSL clustering at surface membranes of erythrocytes, observed by freeze-fracture (Tillack et al. 1983). Similar GSL clusters were observed at the surface of GSL-phosphatidylcholine liposomes without cholesterol (Rock et al. 1990, 1991). c. Clustered GSLs in membrane were found to be insoluble in aqueous medium containing 1\% Triton X-100 or zwitterionic Empigin-BB. The insolubility of GSLs was due to their association with cytoskeletal components and extracellular matrix, which were also insoluble in these detergents (Carter and Hakomori 1981, Okada et al. 1984). d. GSL-dependent adhesion is based on GSL clustering at GSL-enriched microdomain (Kojima and Hakomori 1991b). e. Signaling from growth factor receptor is affected by surrounding GSLs in microdomain (Bremer et al. 1984, 1986, Yates and Rampersaud 1998). f. Association of GPI anchors with Src family kinases (Stefanova et al. 1991). g, h. As shown. 
1. Glysyn

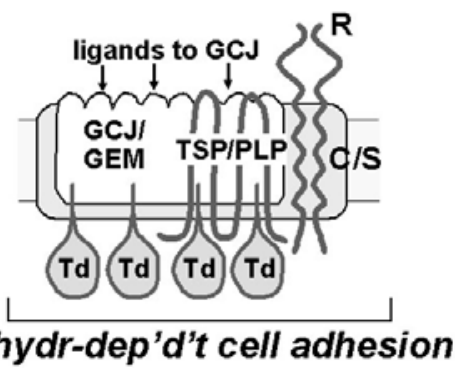

2. caveolae/ raft

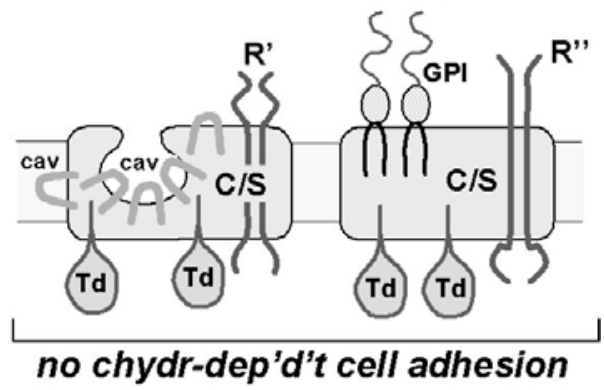

Fig. 3 - Components of microdomains, and their variation. Glycosynapse (\#1) is enriched in clustered glycoconjugate (GCJ) in glycoconjugate-enriched membrane (GEM) to which GCJ ligands bind. GCJ may be GSL, O-linked glycoprotein, or N-linked receptor-type glycoprotein, which are associated with signal transducers (Td), tetraspanins (TSP) (including proteolipid proteins; PLP), and membrane lipids. Caveolae/raft (\#2) contains cholesterol/sphingomyelin-enriched membrane (C/S) and caveolin (cav). $\mathrm{Td}$ are placed in the same way as for glycosynapse. Glycosylphosphatidylinositol (GPI) protein/raft (\#3) is enriched in C/S and GPI anchor linked to defined protein. Td are placed in the same way as for glycosynapse. R, R', R', various growth factor receptors and integrin receptors.

as GSL-phosphatidylcholine liposomes (Fig. 5B). GSL microdomains were originally found to be detergent-insoluble (Okada et al. 1984), and were separated as buoyant, low-density membrane fraction containing cSrc, Src family kinases, small Gproteins (RhoA, Ras, Rac), FAK, and occasionally growth factor receptors (Liu et al. 1996, Mineo et al. 1996, Yamamura et al. 1997, Iwabuchi et al. 1998a, b). GSL microdomains from mouse B16 melanoma cells, highly enriched in GM3 ganglioside, cSrc, RhoA, were separated from "caveolar membrane" or "raft", which are enriched in cholesterol, sphingomyelin, and caveolin. Possible structure of such GSL microdomain is illustrated in Fig. 5C.

GSLs clusters in glycosynapse 1 are involved in adhesion between interfacing cells through carbohydrate-to-carbohydrate interaction, initially observed for teratocarcinoma F9 cell autoaggregation that mimics compaction of preimplantation embryo. This process is based on $\mathrm{Le}^{\mathrm{x}}$ self-recognition in the presence of $\mathrm{Ca}^{2+}$ (Eggens et al. 1989). Cell adhesion mediated by GSL clusters, coupled with initiation of signal transduction, is illustrated schematically in Fig. 5D.

The functional role of $\mathrm{Le}^{\mathrm{x}}$ GSL in glycosynapse
1 was compared to that of embryoglycan carrying multiple $\mathrm{Le}^{\mathrm{x}}$ determinants in mediating autoaggregation of F9 cells (Kojima et al. 1994). Clustered $\mathrm{Le}^{\mathrm{x}}$ carried by GSL or by embryoglycan functioned equally well, in the presence of $\mathrm{Ca}^{2+}$.

Another example of GSL-dependent adhesion through glycosynapse 1 is adhesion of mouse B16 melanoma cell (expressing high level of GM3) to mouse endothelial cells (ECs) (expressing high lactosylceramide (LacCer) or Gg3Cer). Such adhesion is the initial step in B16 cell metastasis (Kojima et al. 1992). This hypothesis was confirmed by the finding that in vivo B16 cell metastasis is inhibited by GM3-liposomes or Gg3-liposomes, but not by sialylparagloboside-liposomes (Otsuji et al. 1995).

The concept of GSL-dependent adhesion was extended to interaction of GM3 with Gg3 (Kojima and Hakomori 1991a, Matsuura et al. 2000), Gb4 with Gb5 or nLc4 (Yu et al. 1998), H with $\mathrm{Le}^{\mathrm{y}}$ (Zhu et al. 1995), and GalCer with sulfatide (Stewart and Boggs 1993, Menikh et al. 1997). Some of the structures involved in GSL-to-GSL trans interaction that induces GSL-dependent adhesion are shown in Fig. 6.

GSL-dependent adhesion through carbohy- 


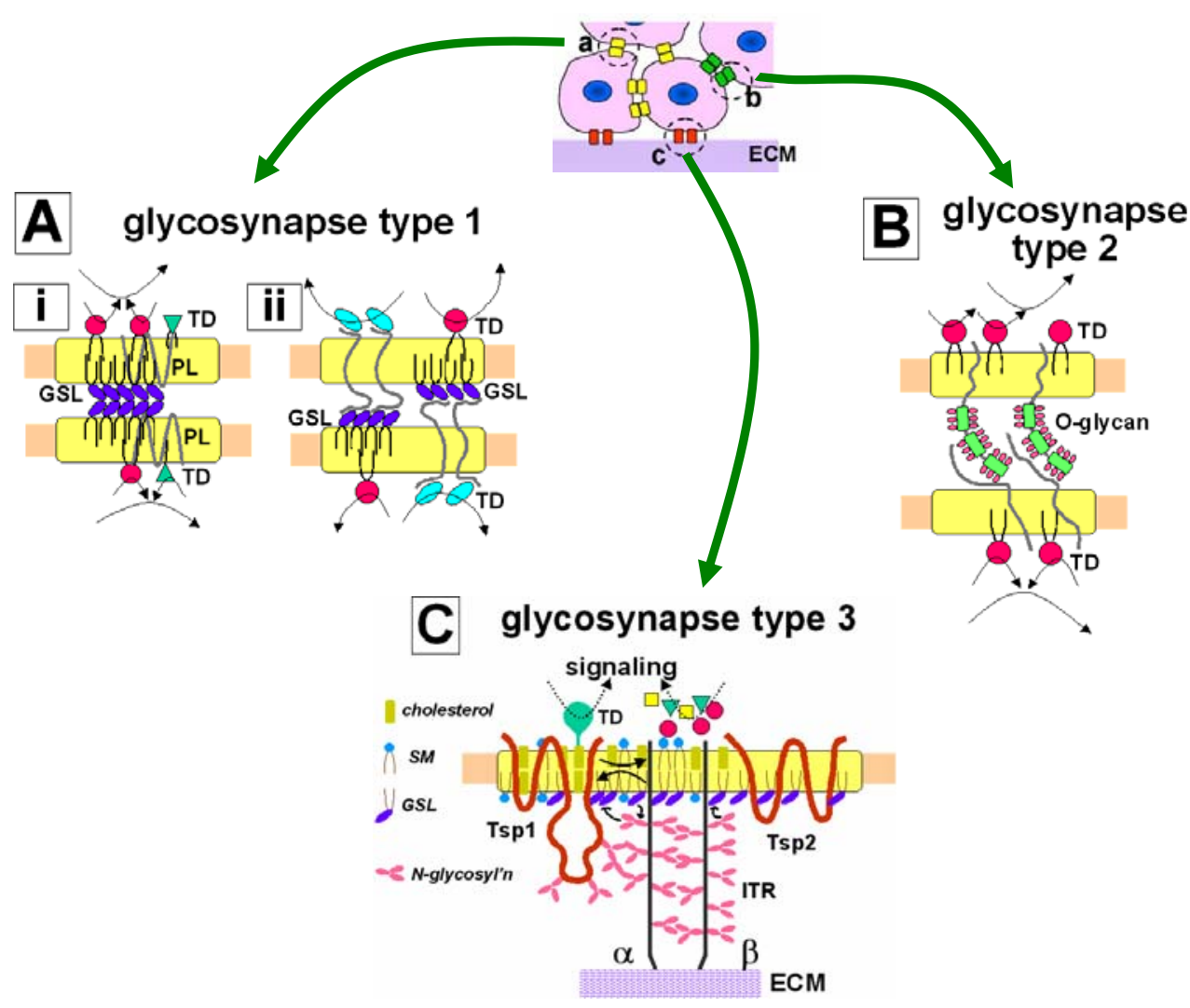

Fig. 4 - Glycosynapses involved in cell-to-cell adhesion, and in cell-to-extracellular matrix (ECM) adhesion. Cell-to-cell adhesion sites (a, $\mathbf{b}$ at top) consist of interfacing microdomains, shown as two contacting oblong shapes. Cell-to-ECM adhesion site (c) involves a different microdomain structure shown as a pair of dark oblongs. Examples of adhesion site a, termed "glycosynapse type 1", are based on GSL-to-GSL interaction (A-i) or GSL-to-binding protein interaction (A-ii), in which GSLs are associated with Td and stabilized by proteolipid (PL). Glycosynapse 2 (B), another cell-to-cell adhesion site, is based on O-linked mucin-type GPs which are recognized by chydr-binding proteins. Both O-linked glycans and their recognizing proteins are associated with Td. Adhesion of cell to ECM (fibronectin, collagen, laminin) is mediated by $\mathrm{N}$-glycosylated adhesion receptor (e.g., integrin receptor, ITR) complexed with TSP and ganglioside; their possible organization is shown in C. Cell adhesion and motility are greatly inhibited when integrin/TSP/ganglioside complex is stabilized by glycosylation.

drate-binding proteins, e.g., siglec-4 or MAG (myelin-associated glycoprotein), which bind preferentially to GD1a, GT1b, or GQ1b (Yang et al. 1996, Schnaar et al. 1998, Vyas et al. 2002).

\subsection{GLYCOSYNAPSE 2: AdHESION MEDIATED By CARBOHYDRATE-TO-PROTEIN INTERACTION}

Mucin-type glycoproteins have tandem repeat of defined peptide core with many Ser/Thr residues, through which multiple O-linked glycans are presented. Various glycosyl structures (sialyl-Le ${ }^{\mathrm{x}}$,
sialyl-Le ${ }^{\mathrm{a}}$, sialyl-Tn) carried by O-linked glycans in mucin-type glycoproteins are the essential epitopes for selectins (Varki 1994, Kannagi 1997, McEver and Cummings 1997), siglecs (Crocker et al. 1994, Crocker and Varki 2001, Ito et al. 2001), and other carbohydrate-binding proteins that mediate adhesion of tumor cells, neutrophils, or peripheral blood mononuclear cells.

We found recently that MUC1 and other mucin-type glycoproteins (see below), together with Src family kinases, are expressed in low-density 


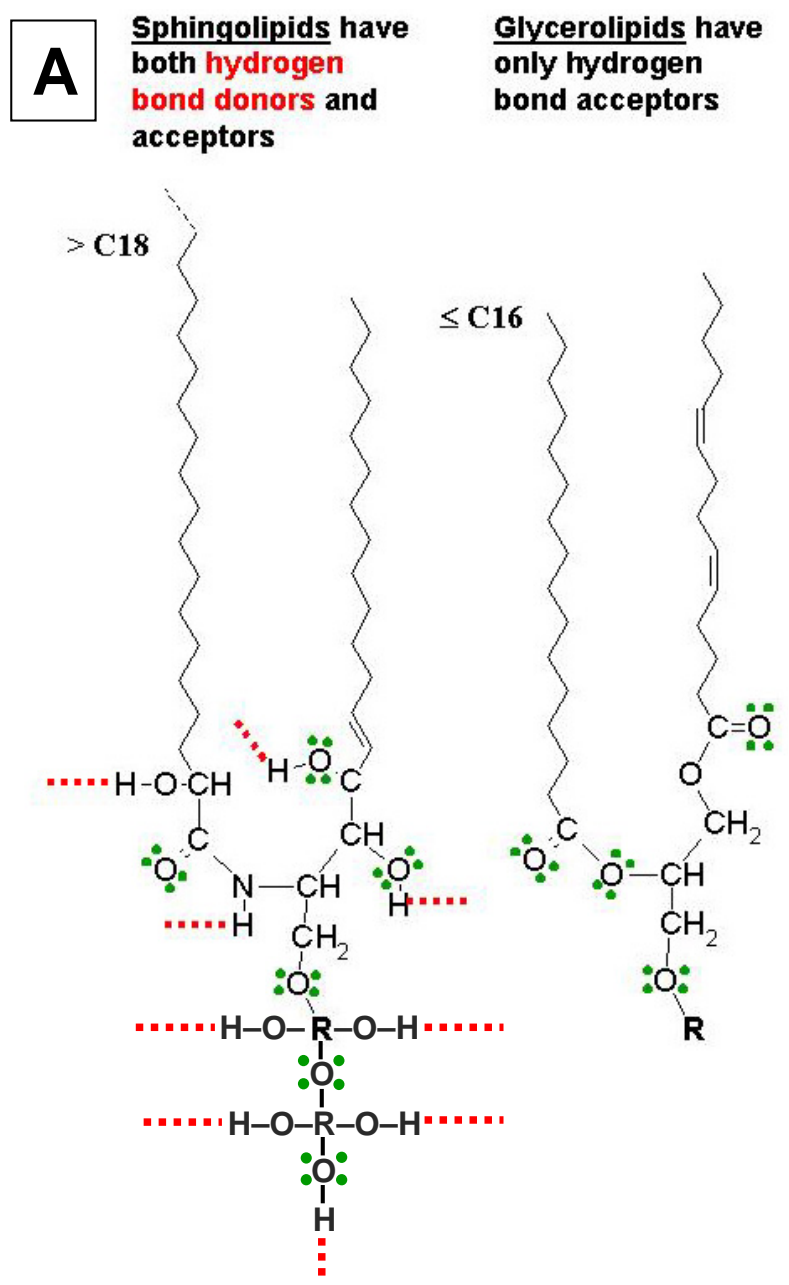

Fig. 5 - GSL clusters as a basis of GSL microdomains and their function. Panel A: Physicalchemical basis of GSL clusters. Sphingolipids and GSLs have hydroxyl groups and aminoacyl groups that provide hydrogen bond donors as well as acceptors. In contrast, glycerolipids have no hydroxyl group and provide only hydrogen bond acceptors. Therefore, intermolecular interaction is much higher between sphingolipids or GSLs. Scheme modified from Pascher (1976). GSLs and SM form "liquidordered (lo ) phase', whereas glycerolipids form "disordered gel phase". This phase difference reflects melting point: GSL $>70^{\circ}$; SM 39-41 ${ }^{\circ}$; glycerophospholipid $<0^{\circ}$ (5). Presence of $\alpha-\mathrm{OH}$ fatty acid increases antigenicity, leading to increased clustering (Kannagi et al. 1983). Comparative chain length of fatty acid and Sph strongly affects antigenicity of GSL, presumably because of enhanced clustering (Watanabe et al. 1976, Yoshino et al. 1982).

membrane fraction, prepared in Brij58 or $\mathrm{Na}_{2} \mathrm{CO}_{3}$, of T-cell lymphoma cell lines Jurkat and HUT78. MUC1 microdomains are characterized by having Src family kinases (Yes, Fyn, lck56), CD45, and P-selectin glycoprotein ligand-1 (PSGL-1). Impor- tantly, both CD45 and PSGL-1 are mucin-type glycoproteins having structural unit similar to MUC1 (Handa et al. 2001). These preliminary data are shown in Fig. 7A-E. Coexistence of MUC1, PSGL1 , and CD45 in the same low-density membrane mi- 
Gb4, glycophorin on human RBCs

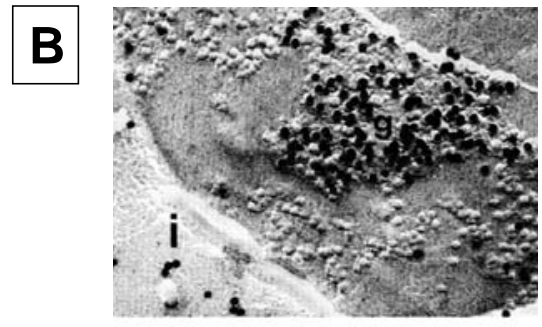

GM3 on T-cells

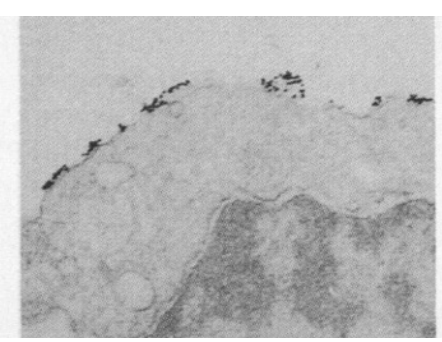

GM1 on liposome, without chol.

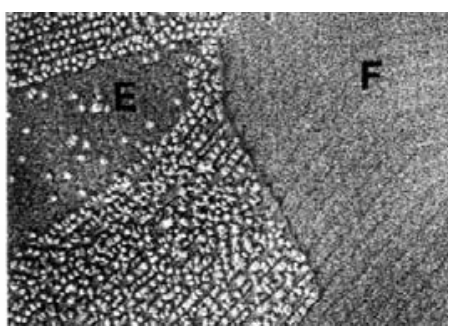

polysialoganglioside in fish brain neuronal junction

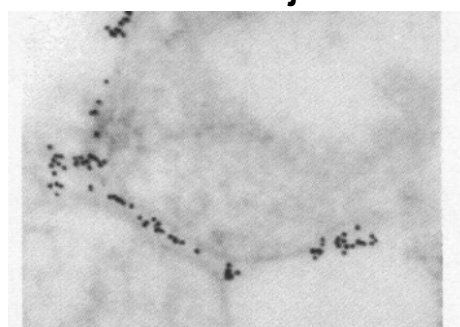

Fig. 5 - Panel B: Upper left: GSL clusters and GP clusters at erythrocyte surface membrane (Tillack et al 1983). Upper right: GM1 clusters on PC-liposome without cholesterol (Rock et al. 1991). These two photos are from scanning EM with freeze-fracture technique. Lower left: GM3 clusters on T-cells observed by transmission EM (Sorice et al. 1997). Lower right: polysialoganglioside clusters on neuronal cells, particularly at brain neuronal junction (Rahmann et al. 1994).

crodomain of the same T-cell line may not be coincidental, but its functional significance remains to be studied. The functional notion of MUC1 in Tcells has been studied recently, revealing that: (i) activated but not resting human T-cells express and secrete MUC1 (Agrawal et al. 1998a); (ii) activated T-cells express MUC1 at "leading edge" associated with gangliosides (Correa et al. 2003); (iii) soluble MUC-1 inhibits T-cell proliferation (Agrawal et al. 1998b, c). These observations suggest that MUC1 in T-cells may define T-cell activation and migration, and that excessive MUC1 expression may inhibit activation. A recent study indicates that MUC1 expression in Jurkat cells is closely associated with IL2 secretion, since "knock-down" of MUC1 by RNAi approach blocked IL2 secretion (Handa K, Andersen S, Hakomori S, unpubl. data). MUC1 may act as sensor of environmental change to transmit signals into cells to promote T-cell survival through IL2 pro- duction. The presence of mucin-type glycoproteins in glycosynapse 2 requires extensive further study.

Presence of mucin-type glycoproteins in Tcells was not known until very recently (Agrawal et al. 1998a, c). We found unexpectedly that three mucin-type glycoproteins, MUC1, PSGL-1, and CD45, are all resistant to $1 \%$ Brij 48 or $500 \mathrm{mM}$ $\mathrm{Na}_{2} \mathrm{CO}_{3}$, and all present in low-density membrane fraction, associated with Src kinases (Handa et al. 2001). In contrast, mucin-type glycoproteins are classically well-known components of mucous membranes and their secretions. Many common human cancers are derived from secretory epithelial cells (endodermal epithelia) in which mucin-type glycoproteins are abundant, and carry typical tumorassociated carbohydrate antigens such as sialyl-Le ${ }^{\mathrm{x}}$, sialyl-Le ${ }^{\mathrm{a}}$, and sialyl-Tn. Our preliminary studies indicate that MUC1 and MUC4 expressed in mammary carcinoma cell line MCF7 are present in low- 


\begin{tabular}{|c|c|c|c|c|c|c|c|c|c|c|c|}
\hline \multirow[b]{3}{*}{ GSL glycosynapse } & \multirow{3}{*}{$\begin{array}{l}\text { GM3 } \\
+++\end{array}$} & \multirow{3}{*}{$\begin{array}{c}\text { SM } \\
+\end{array}$} & \multirow{3}{*}{$\begin{array}{c}\text { Chol } \\
+\end{array}$} & \multirow{3}{*}{$\begin{array}{c}\text { Cav } \\
-\end{array}$} & \multirow[b]{2}{*}{ PL } & \multirow[b]{2}{*}{ SFK } & \multirow[b]{2}{*}{ RhoA } & \multirow[b]{2}{*}{ FAK } & \multirow[b]{2}{*}{ Ras } & \multicolumn{2}{|c|}{ suscept. to: } \\
\hline & & & & & & & & & & SaSph & filipin \\
\hline & & & & & + & + & + & + & - & + & - \\
\hline caveolae /raft & - & ++ & +++ & + & n.d. & - & - & - & + & - & + \\
\hline
\end{tabular}

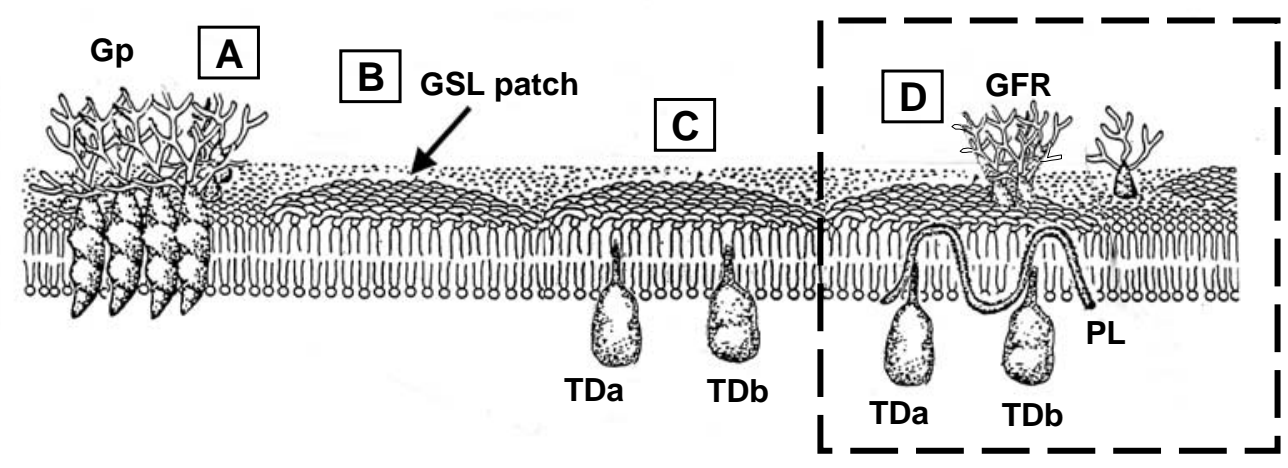

Fig. 5 - Panel C: Top: Distinction of GSL microdomain (glycosynapse) from caveolar/raft membrane. Bottom: Glycoprotein (Gp) clusters (A) are separated from GSL microdomain (GSL patch) (B), which are often associated with various signal transducers (TDa, TDb) $(\mathbf{C})$. Proteolipids (PL) are often associated with GSL/TD complex to facilitate association of GSLs with signal transducers and regulate GSL-dependent signal transduction. Presence of three or four components (GSL, PL or tetraspanin, and multiple TDs) is essential for assembly of GSL microdomain (D). Growth factor receptors (GFR) are occasionally associated with GSL microdomain, depending on cell growth stimulation. Integrin receptors associated with tetraspanin are often present in GSL microdomain (see Fig. 4C), but are not shown in the present figure.
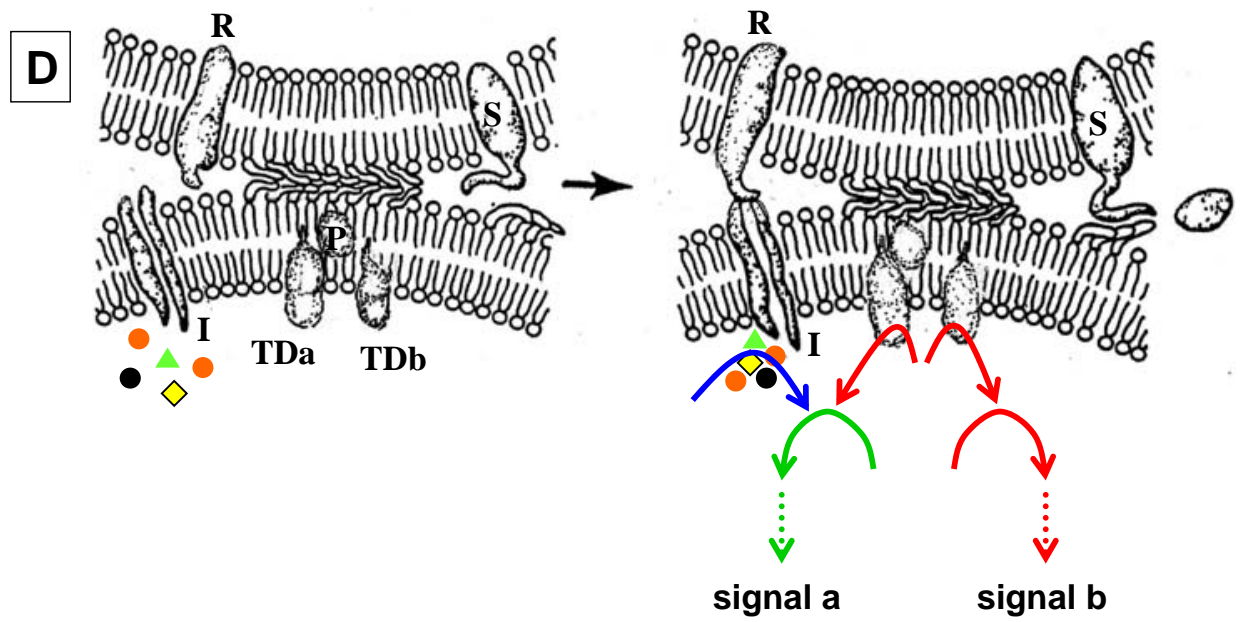

Fig. 5 - Panel D: Cell adhesion mediated by GSL microdomains through GSL-to-GSL trans interaction, which activates signal transducers (TDa, $\mathrm{TDb}$ ) leading to change of cellular phenotype. This mechanism is also shown in Fig. 4A-i as a part of GSL-dependent cell adhesion. 
Lex/ Ley/ H interaction

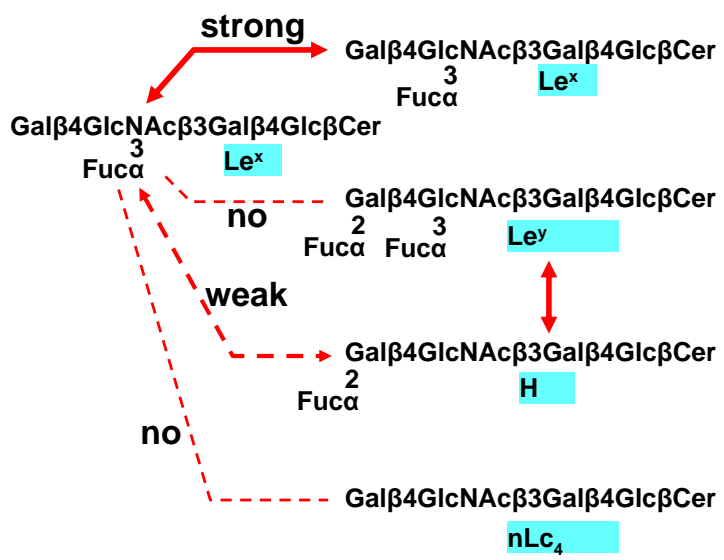

\section{GM3 interaction}

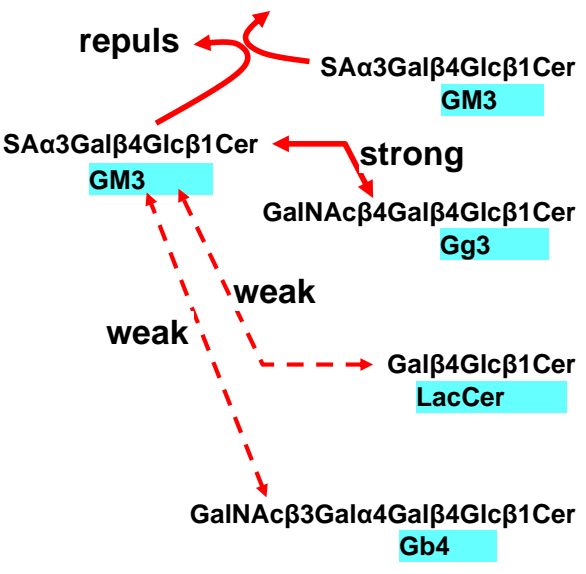

Fig. 6 - Some of the structures involved in GSL-to-GSL trans interaction that mediates GSL-dependent adhesion. Left panel: strong adhesion induced by $\mathrm{Le}^{\mathrm{x}}$ self-recognition or $\mathrm{H}-\mathrm{Le}^{\mathrm{y}}$ interaction. Right panel: strong interaction between GM3 and Gg3, and repulsion between GM3 molecules.

density membrane fraction, associated with cSrc, CD9, and FAK (Steelant et al. 2002). We expect great future interest in characterization of glycosynapse 2 in various types of human cancer, which is involved in adhesion of tumor cells to ECs to initiate metastasis. Thus, microdomains having mucin-type glycoproteins organized with Src family kinases, involved in carbohydrate-dependent cell adhesion and signaling, are collectively termed "glycosynapse 2'.

\subsection{Glycosynapse 3: Microdomains control- LING CARBOHYDRATE-DEPENDENT MODULA- TION OF CELL ADHESION THROUGH ADHESIVE PROTEIN RECEPTOR}

The best-studied adhesion receptors are integrins, which are often associated with tetraspanins (TSPs). Cell adhesion to extracellular matrix (ECM) is mediated by various combinations of $\alpha$ and $\beta$ subunits of integrins (Ruoslahti 1991, Hynes 1992), whose association with tetraspanins (for review see Hemler 2003) depends on N-glycosylation status of both integrins and TSPs, as well as surrounding gangliosides (Ono et al. 1999, 2000, 2001).
TSPs CD9 (Miyake et al. 1991) and CD82 (Dong et al. 1995) were identified as inhibitory factors on tumor cell motility and metastasis. Their effect depends highly on glycosylation status. In order to clarify such effect of glycosylation on cell motility mediated by integrin/TSP/ganglioside complex, we performed the following series of experiments.

(i) IdID cells defective in UDP-Gal 4-epimerase (Kingsley et al. 1986, Krieger et al. 1989 ), which cannot synthesize GM3 or complete N-glycosylation unless cultured in insulin-transferrin-selenium medium (ITS) medium with addition of galactose (+Gal condition), were transfected with CD9 or CD82 gene, giving rise to ldlD/CD9 and ldlD/CD82 cell lines respectively (Fig. 8A,B). We found, unexpectedly, that motility of these CD9 and CD82 transfectants was greatly enhanced under -Gal condition, i.e., when GM3 is absent and $\mathrm{N}$-glycosylation is incomplete. In contrast, motility was strongly inhibited under $+\mathrm{Gal}$ condition, whereby endogenous GM3 synthesis occurs and N-glycosylation of CD82 is completed (Ono et al. 1999) (Fig. 8C).

(ii) Because the ligand of integrin $\alpha 3$ is LN5, $\alpha 3$ / LN5-dependent ldID cell motility was greatly in- 


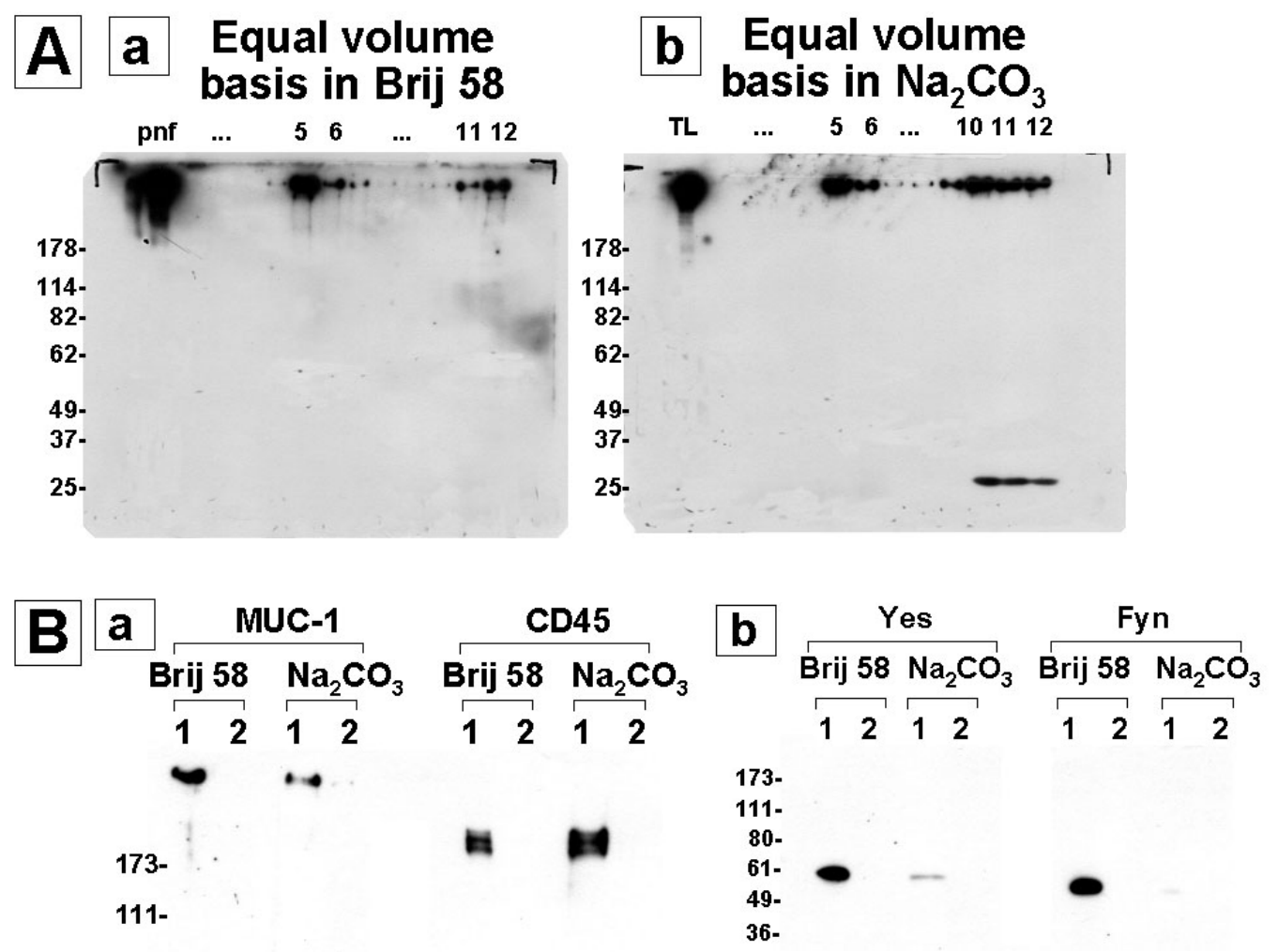

Fig. 7 - MUC1, CD45, and src family kinases (Yes, Fyn) are all enriched in low-density membrane fraction (glycosynapse 2).

Panel A: MUC1 in human T-cell line HUT78 is highly enriched in low-density membrane fraction (Fr. 5). a: MUC1 distribution pattern of fraction separated by sucrose density gradient centrifugation after lysis in $0.5 \%$ Brij 58 lysis buffer. b: MUC1 distribution pattern in hypertonic alkaline $\left(500 \mathrm{mM} \mathrm{Na} 2 \mathrm{CO}_{3}\right)$ solution. For both panels, equal volume of each fraction $(10 \mu 1)$ was subjected to SDS-PAGE followed by Western blotting with anti-MUC1 mAb B27-29. pnf, postnuclear fraction. TL, total lysate. Panel B: MUC1, CD45, Yes, and Fyn are co-present and enriched in low-density membrane (Fr. 5). Fractions prepared in 0.5\% Brij 58 lysis buffer are compared with fractions prepared in $500 \mathrm{mM} \mathrm{Na}_{2} \mathrm{CO}_{3}$. a, left: MUC1 in Fr. 5 (lane 1) and soluble Fr. 10-12 (lane 2), Western blotted with anti-MUC1 mAb; right: same as left, but blotted with anti-CD45 mAb. b, left: Western blotted with anti-Yes mAb; right, blotted with anti-Fyn mAb. Lanes 1 and 2 as in “a”'. A similar enrichment of PSGL-1 and Lck56 was observed in Fr. 5 prepared in Brij 58 or $\mathrm{Na}_{2} \mathrm{CO}_{3}$ (data not shown).

hibited when $\alpha 3 / \mathrm{CD} 9 / \mathrm{GM} 3$ complex was formed under + Gal condition, but the motility was greatly enhanced under -Gal condition, whereby complex appeared to be dissociated (Fig. 9A,B). The enhanced motility under -Gal condition was moderately reduced, while the suppressed motility under + Gal condition was greatly enhanced, when anti- $\alpha 3$ antibodies were added (Fig. 9B-b). These observations confirm that the motility-inhibitory effect of $\alpha 3 / \mathrm{CD} 9 / \mathrm{GM} 3$ complex occurs primarily at the cell surface, and that the effect is based on interac- tion of $\alpha 3$ with LN5.

(iii) The motility-inhibitory effect of CD9 or CD82 is suggested by their capability to form complex with integrin receptors (Mannion et al. 1996, Ono et al. 2000, 2001). Motility of three colorectal cancer lines expressing high CD9 level was reduced greatly only upon addition of exogenous GM3 $(10,50 \mu \mathrm{m})$ (Fig. 10A), possibly through CD9/GM3/integrin receptor complex, as evidenced by addition of photoactivatable GM3 to HRT18 cells (Fig. 10B). 

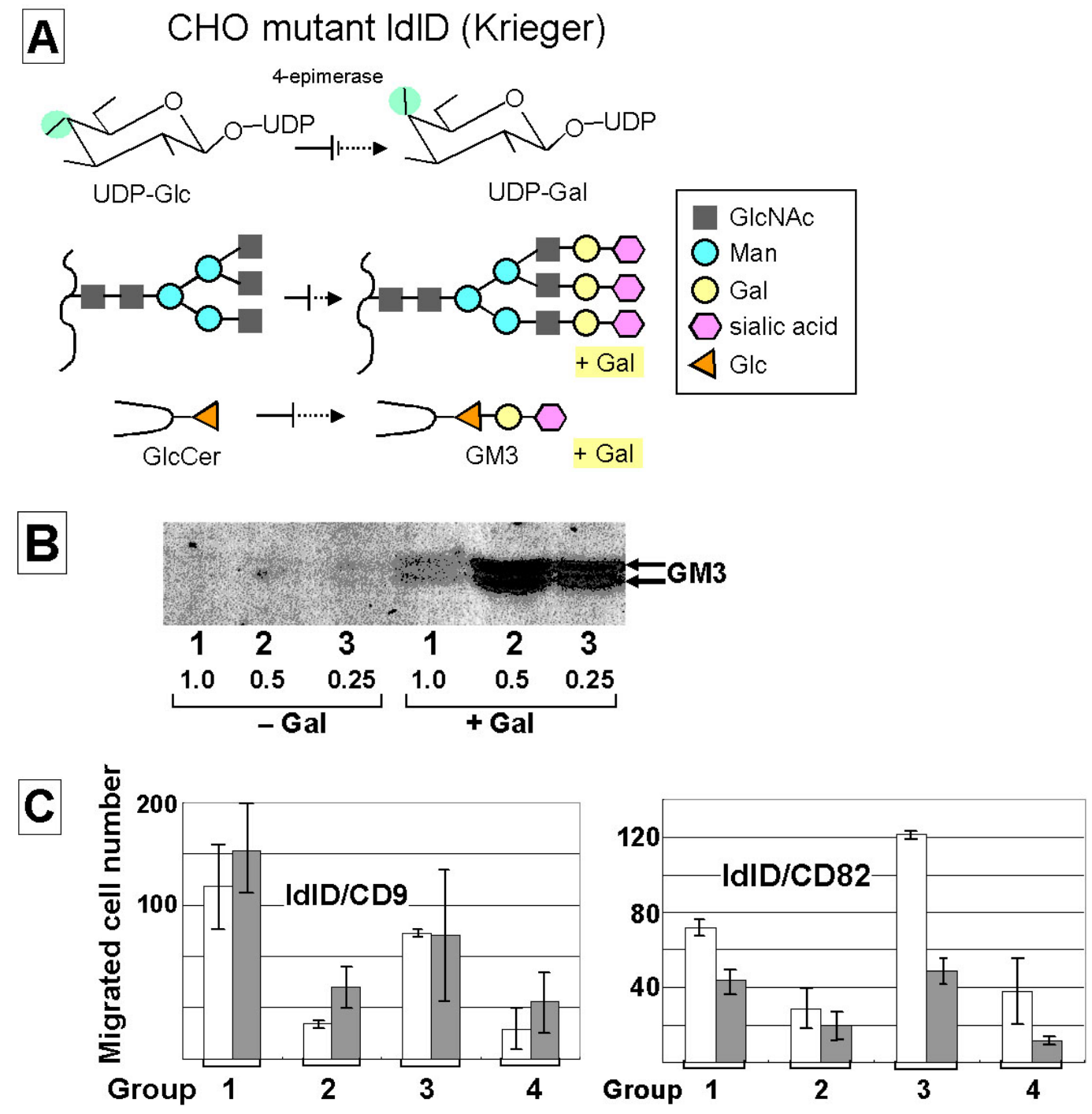

Fig. 8 - Effect of glycosylation on cell motility through tetraspanin CD9 or CD82, demonstrated in CHO mutant ldID cells. Panel A: CHO mutant ldID cells (Krieger's mutant) are defective in UDP-Glc 4-epimerase. Cells are incapable of synthesizing UDPGal unless Gal is added to culture medium. Therefore, N-linked structure cannot be extended completely, or GlcCer is not converted to GM3. Panel B: GM3 is absent in GEM when ldID cells are grown under-Gal condition, but is present in GEM when cells are grown under $+\mathrm{Gal}$ condition. Presence of GM3 is more clear when GEM is prepared in $0.5 \%$ or $0.25 \%$ Triton X-100, but less clear when prepared in 1\% Triton X-100. Panel C: Transwell motility of ldlD/CD9 (left) and ldlD/CD82 (right). ldlD/CD9 or ldID/CD82 were established by transfection of ldID cells with CD9 or CD82 gene. Their motility was determined using Transwell membrane, with the lower surface coated with Matrigel. Cells in Ham's F-12 (with 0.25\% BSA) were allowed to migrate to the lower surface during $24 \mathrm{hr}$, and counted. Data are shown for two clones (white and shaded bar respectively) grown in ITS medium -Gal (group 1), +Gal (group 2), +GalNAc (group 3), or +Gal+GalNAc (group 4). Note that cell motility was inhibited only in the presence of Gal. 

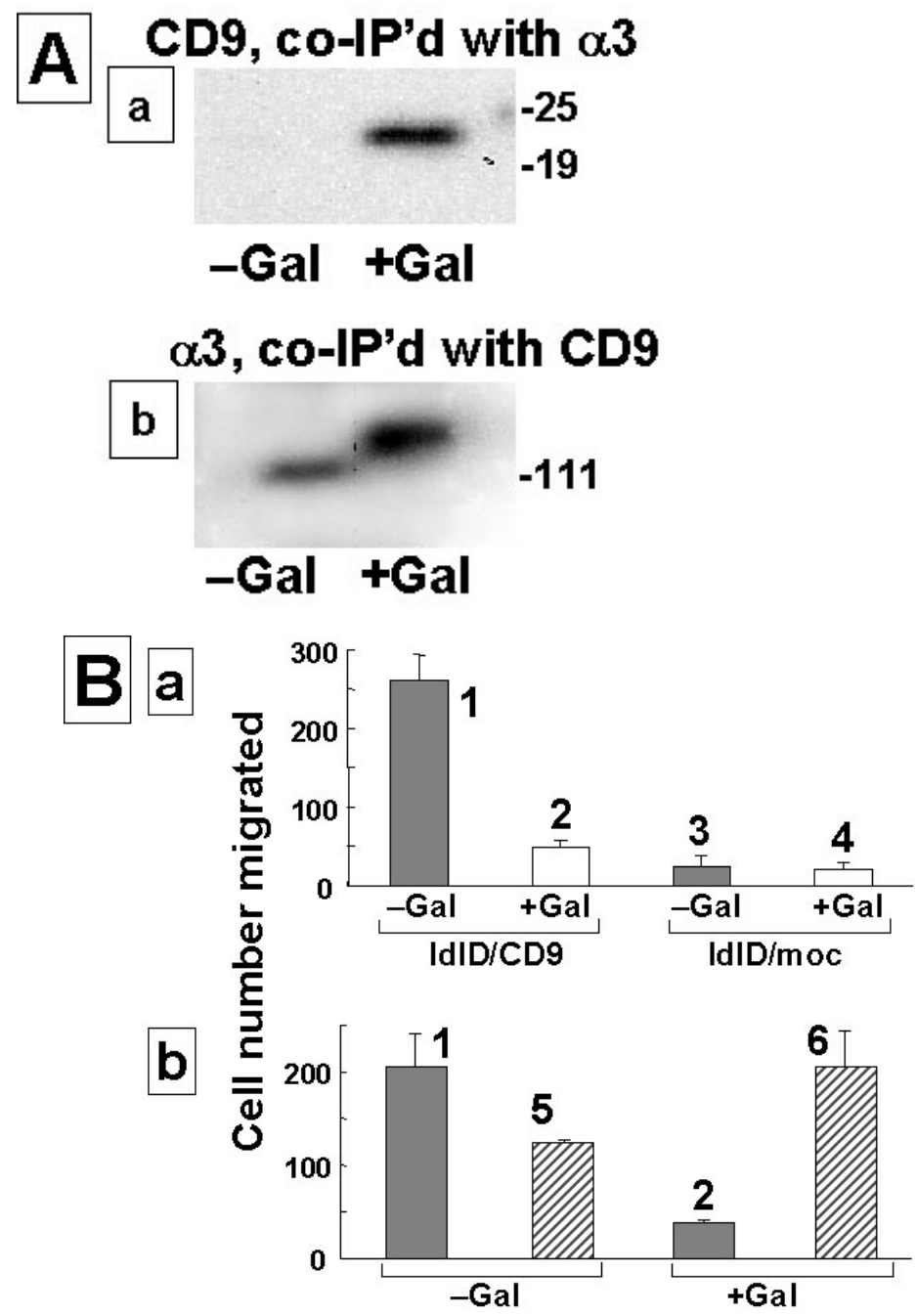

Fig. 9 - GM3-induced motility-inhibitory effect of integrin $\alpha$ 3/CD9/GM3 complex. Panel A: $\alpha 3$, CD9, and GM3 form a complex under +Gal condition, whereby endogenous GM3 synthesis and complete N-glycosylation occur. ldID/CD9 cells were grown under - Gal or + Gal condition, and cell lysate was subjected to co-IP. a: CD9 co-IP'd with anti- $\alpha 3$ from lysate of cells grown in -Gal vs. + Gal condition. Only lysate from + Gal cells gave co-IP of CD9 with anti- $\alpha 3$. b: $\alpha 3$ co-IP'd with anti-CD9 from Fr. 5 (GEM), prepared from cells grown under -Gal vs. +Gal condition. Note that $\alpha 3$ band co-IP'd with anti-CD9 was greatly enhanced in + Gal vs. -Gal condition. Panel B: Laminin-5 (LN5)-dependent motility of 1dID/CD9 cells is inhibited under +Gal condition, whereby endogenous GM3 synthesis and N-glycosylation of $\alpha 3$ integrin occur. The upper surface of Transwell membrane was coated with LN5, and ldlD/CD9 cells in F12 medium were placed in the upper compartment. Cell migrated to lower surface of the membrane were counted. a. The LN5-dependent motility of the cells was greatly suppressed under +Gal condition (column $\mathbf{2}$ ), whereas motility was very low and unaffected by $-\mathrm{Gal} v s$. +Gal in parental ldlD/moc cells (3 and 4). b. The high motility of ldlD/CD9 cells on LN5-coated Transwell membrane under-Gal (1) was slightly reduced in the presence of anti- $\alpha 3$ antibody (5). LN5-dependent motility was suppressed strongly under $+\mathrm{Gal}$ (2) but was enhanced in the presence of anti- $\alpha 3 \mathrm{Ab}(\mathbf{6})$, i.e., $\alpha 3 / \mathrm{CD} 9 / \mathrm{GM} 3$ complex is present at the cell surface, and is susceptible to anti- $\alpha 3 \mathrm{Ab}$. 


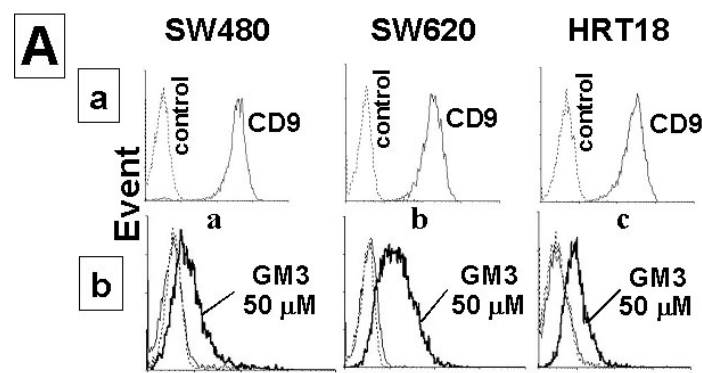

Log fluorescence intensity
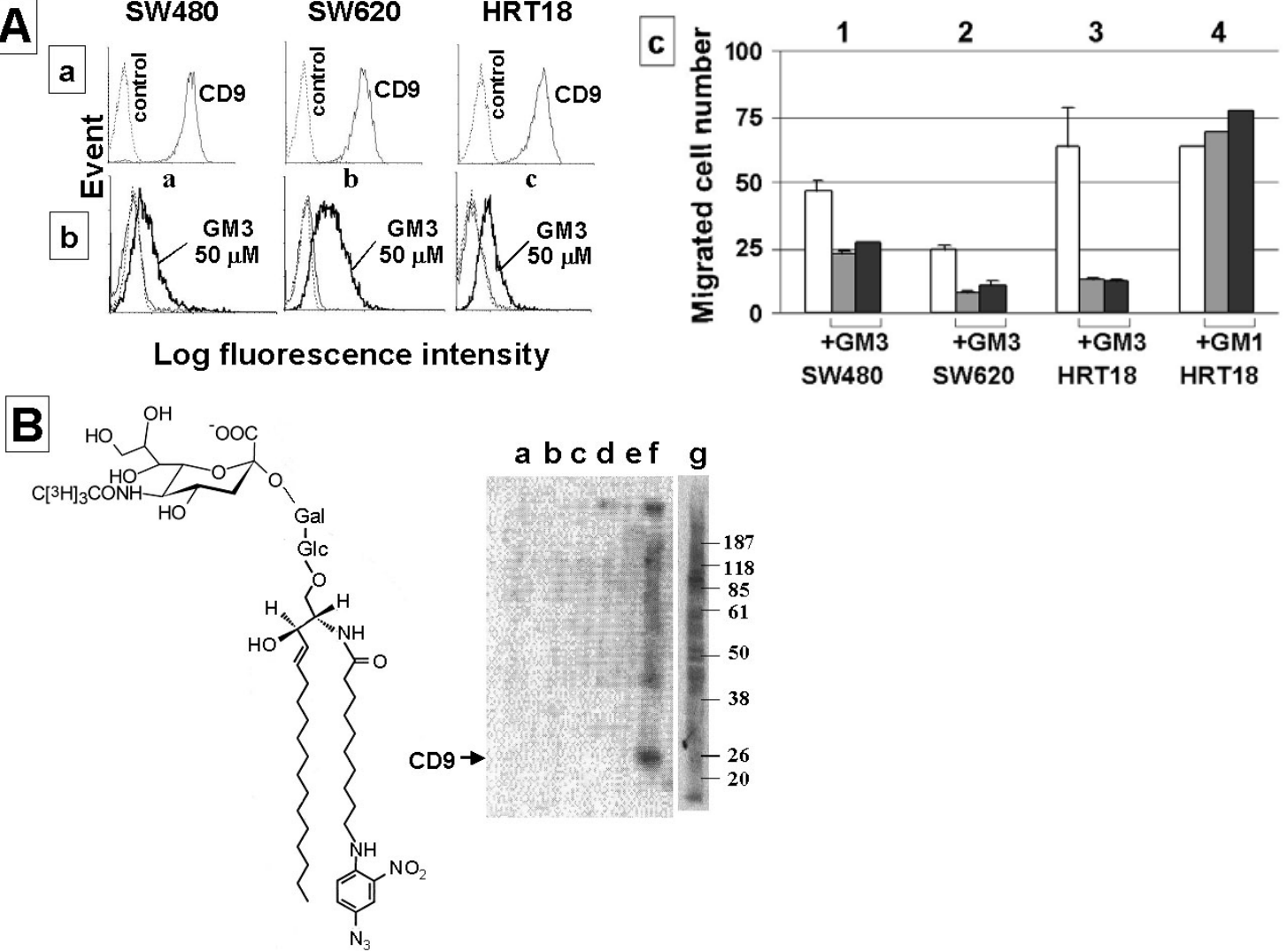

Fig. 10 - Effect of GM3 on CD9-dependent cell motility inhibition: GM3 is a co-factor of CD9. Panel A: Colorectal cancer cell lines expressing high CD9 level are susceptible to GM3-induced motility inhibition. Three colorectal cancer cell lines (SW480, SW620, and HRT18) express equally high CD9 levels (a); but low levels of GM3 unless it is added exogenously (b). Haptotactic motility of these cells is strongly inhibited by incubation with $10 \mu \mathrm{M}$ (gray column) or $50 \mu \mathrm{M}$ (black column) GM3 (c-1, c-2, c-3) but not with the same concentration of GM1 (c-4). Panel B: Interaction of CD9 and other membrane proteins with photoactivatable GM3. HRT18 cells were used because they express high level of CD9 and their motility is susceptible to GM3. Cells were treated with photoactivatable ${ }^{3} \mathrm{H}$-labeled GM3 (structure shown at left) plus regular GM3, washed, and UV irradiated. Cells were then lysed, and subjected to IP with normal mouse IgG as control (lane a), anti-integrin $\beta 1$ (lane b), anti- $\alpha 6$ (lane c), anti- $\alpha 4$ (lane d), anti- $\alpha 3$ (lane e), or anti-CD9 (lane f). Lane g, total lysate of HRT18 cells (60 $\mu \mathrm{g}$ protein).

\section{PERSPECTIVES ON GLYCOSYNAPSES IN MOLECULAR CELL BIOLOGY}

I would like to present a few perspectives based on the concept of glycosynapse.

\section{PHENOTYPIC VARIABILITY AND GLYCOSYNAPSE}

Current molecular cell biology has advanced greatly along the scenario of its "central dogma": DNA $\rightarrow$ RNA $\rightarrow$ protein. The total number of genes in genome of Caenorhabditis elegans was determined as 20,000 in 1998 (The C. elegans Sequencing Consortium 1998). Many molecular biologists expected that the number of genes in the human genome would be 4-10 times higher than this, because of the much greater complexity of phenotypes in human cells as compared to nematode. The number of human genes was clarified 3 years later, surprisingly, as 30,000 (Venter et al. 2001). How is this minor difference in gene number related to such a large difference in complexity of 
phenotypes between nematodes and humans? Variability in splicing of DNA? Variability in mode of transcription factor effect? Epigenetic effect, i.e., change of gene effect without change of DNA sequence (acetylation or methylation of DNA, or chromatin effect in nucleosome)? Recent studies indicate the presence of hitherto-unknown DNA located outside conventional genome; such "extraterritorial" DNA may encode unusual RNA (e.g., "riboswitch") which modulates messenger function or other functions involved in the "central dogma", e.g., (Gibbs 2003a, b).

While it is essential to consider these recent breakthrough developments in addition to classic genome/proteome concepts in order to understand the complexity of phenotypes, it is also important to recognize that post-translational modification of proteins increases complexity. $60 \%$ of proteins are modified by (i) $\mathrm{N}$ - or O-glycosylation; (ii) lipidation (i.e., palmitoylation or myristoylation); (iii) association with ganglioside or GSL leading to alteration of function. Processes i, ii, and iii are obviously not based simply on the "central dogma", but are controlled by assembly of secondary gene products. Variability of glycosylation in glycoproteins and GSLs is shown in Table I.

This variability in molecules suggests creation of further variability in molecular assembly of membranes, which is the theme of this article, and which I have illustrated in three examples of glycosynapse. To say that only three types exist is certainly an oversimplification. There are undoubtedly a much larger number, showing a wide range of flexibility in response to cellular environment.

\section{CELL SOCIAL FUNCTION AND GLYCOSYNAPSE}

Cell surfaces are enriched in carbohydrates, which are assumed to be involved in cell "social functions" (e.g., recognition, adhesion). This line of study is currently a major theme in cell biology, in contrast to classic molecular cell biology based on the "central dogma". Cell adhesion is associated with signal transduction to define cellular phenotype. The con- cept of glycosynapse helps explain the molecular mechanisms by which cells recognize each other and undergo phenotypic changes such as differentiation, development, oncogenic transformation, metastasis, apoptosis, etc.

Various disease processes can be elucidated through study of glycosynapse structure and function. A few examples are: (i) Oncogenic transformation and invasion through adhesion of tumor cells to ECs through glycosynapse 1 or 2. (ii) Enhanced or inhibited motility/invasiveness through interaction of ECM with integrin/tetraspanin/ganglioside complex (glycosynapse 3). (iii) Many infectious agents are targeted to GSLs or GPs in glycosynapses. Among these, GSL receptors are best elucidated so far. (iv) Accumulation of neutrophils or eosinophils at inflammatory lesion is the key event during inflammatory processes. Such accumulation is based on neutrophil or eosinophil binding to ECs mediated by myeloglycan, which is present in glycosynapse. (v) Neuronal cell function in brain or central nervous system is maintained by nerve growth factor (NGF) receptor or brain-derived growth factor (BDGF) receptor, whose functions are modulated by surrounding gangliosides or GSLs in glycosynapse (Mutoh et al. 1995, Sakakura et al. 1996, Prinetti et al. 1999).

Elucidation of structure and function of glycosynapses involved in these disease processes is expected to lead to methods for prevention and cure of specific diseases.

\section{RESUMO}

O conceito de microdomínios em membrana plasmática foi desenvolvido há mais de duas décadas, após a observação da polaridade da membrana baseada no agrupamento de componentes específicos da membrana. Microdomínios envolvidos na adesão celular dependente de carboidrato, com transdução de sinal que afeta o fenótipo celular são denominados "glicosinapses". Três tipos de glicosinapse foram observados: "tipo 1" que possue glicoesfingolipídio associado com transdutores de sinal (proteínas $\mathrm{G}$ pequenas, cSrc, cinases da família $\mathrm{Src}$ ) e proteolipídios; "tipo 2" que possue glycoproteínas O-ligadas tipo mucina associadas com cinases da família Scr; e "tipo 3" 
TABLE I

Variability of glycosylation in glycoproteins and GSLs.

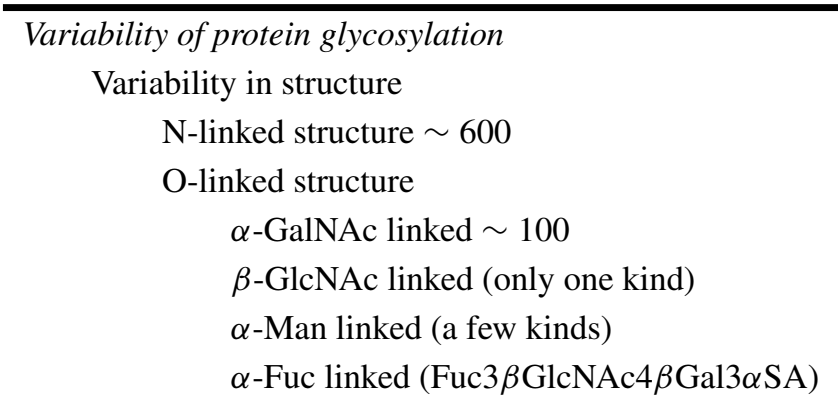

Variability in glycosylation site: countless

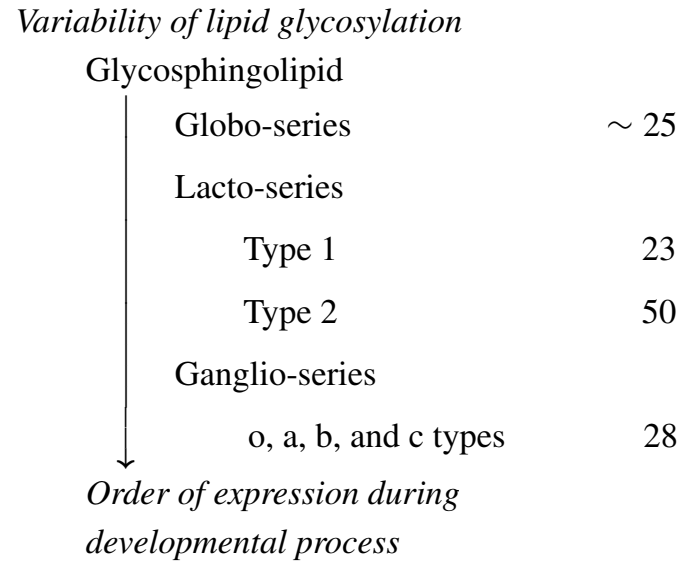

\section{Glyceroglycolipid \\ Seminolipid}

Types of association of GSL or glyceroglycolipid with functional proteins in membrane Countless

que possue receptor de integrina, com glycanas $\mathrm{N}$-ligadas, complexado com tetraspanina e gangliosídio. Tipos celulares diferentes são caracterizados pela presença de tipos específicos de glicosinapse ou suas combinações, cuja adesão induz transdução de sinal para facilitar ou inibir a sinalização. Ex., a sinalização através da glicosinapse tipo 3 inibe mobilidade celular e a diferenciação. Glicosinapses são distintas dos microdomínios conhecidos classicamente como "caveolas", "membrana caveolar", ou mais recentemente "rafts lipídicos", os quais não estão envolvidos na adesão celular dependente de carboidrato. Glicosinapses tipo 1 e tipo 3 são resistentes a regentes que se ligam ao colesterol, enquanto a estrututa e função de "membrana caveolar" ou "rafts lipídicos" são sensíveis a esses reagentes. Vários dados sugerem um papel funcional para as glicosinapses durante a diferenciação, o desenvolvimento e a transformação oncogênica.

Palavras-chave: interação carboidrato-carboidrato, proteína que se liga ao carboidrato, integrina, tetraspanina, receptor de fator de crescimento. 


\section{REFERENCES}

Agrawal B, Krantz MJ, Parker J and LongeneCKER BM. 1998a. Expression of MUC1 mucin on activated human $\mathrm{T}$ cells: implications for a role of MUC1 in normal immune regulation. Cancer Res 58: 4079-4081.

Agrawal B, Gendler SJ AND Longenecker BM. 1998b. The biological role of mucins in cellular interactions and immune regulation: prospects for cancer immunotherapy. Mol Med Today 9: 397-403.

Agrawal B, Krantz MJ, Reddish MA and LongeNECKER BM. 1998c. Cancer-associated MUC1 mucin inhibits human T-cell proliferation, which is reversible by IL-2. Nature Medicine 4: 43-49.

ANDERSON RGW. 1998. The caveolae membrane system. Annu Rev Biochem 67: 199-225.

Arreaza G, Melkonian KA, Lafevre-Bernt M and Brown DA. 1994. Triton X-100-resistant membrane complexes from cultured kidney epithelial cells contain the Src family protein tyrosine kinase p62yes. J Biol Chem 269: 19123-19127.

Bremer EG, Hakomori S, Bowen-Pope DF, Raines EW AND Ross R. 1984. Ganglioside-mediated modulation of cell growth, growth factor binding, and receptor phosphorylation. J Biol Chem 259: 68186825.

Bremer EG, Schlessinger J And Hakomori S. 1986. Ganglioside-mediated modulation of cell growth. Specific effects of GM3 on tyrosine phosphorylation of the epidermal growth factor receptor. J Biol Chem 261: 2434-2440.

Bromley SK, Burack WR, Johnson KG, Somersalo K, Sims TN, Sumen C, Davis MM, Shaw AS, Allen PM AND Dustin ML. 2001. The immunological synapse. Annu Rev Immunol 19: 375-396.

Brown DA AND London E. 1997. Structure of detergent-resistant membrane domains: does phase separation occur in biological membranes? Biochem Biophys Res Commun 240: 1-7.

Carter WG and Hakomori S. 1981. A new cell surface, detergent-insoluble glycoprotein matrix of human and hamster fibroblasts. The role of disulfide bonds in stabilization of the matrix. J Biol Chem 256: 6953-6960.

Correa I, Plunkett T, Vlad A, Mungul A, Cande-
LORA-Kettel J, Burchell JM, TAYlor-PaPAdIMITRIOU J AND FINN OJ. 2003. Form and pattern of MUC1 expression on T cells activated in vivo or in vitro suggests a function in T-cell migration. Immunology 108: 32-41.

Crocker PR and Varki A. 2001. Siglecs in the immune system. Immunology 103: 137-145.

Crocker PR, Mucklow S, Bouckson V, McWilliam A, Willis AC, Gordon S, Milon G, Kelm S and BRADFIELD P. 1994. Sialoadhesin, a macrophage sialic acid binding receptor for haemopoietic cells with 17 immunoglobulin-like domains. EMBO J 13: 4490-4503.

Dong J-T, LAmb PW, Rinker-Schaeffer CW, VukaNOVIC J, ICHIKAWA T, IsAaCS JT AND BARRETT JC. 1995. KAI1, a metastasis suppressor gene for prostate cancer on human chromosome 11p11.2. Science 268: $884-886$

Eggens I, Fenderson BA, Toyokuni T, Dean B, Stroud MR AND HaKomori S. 1989. Specific interaction between Lex and Lex determinants. A possible basis for cell recognition in preimplantation embryos and in embryonal carcinoma cells. J Biol Chem 264: 9476-9484.

Forstner GG and Wherrett JR. 1973. Plasma membrane and mucosal glycosphingolipids in the rat intestine. Biochim Biophys Acta 306: 446-459.

Forstner GG, Tanaka K and Isselbacher KJ. 1968. Lipid composition of the isolated rat intestinal microvillus membrane. Biochem J 109: 51-59.

Gibis WW. 2003a. The unseen genome: gems among the junk. Sci Am 289: 46-53.

Gibis WW. 2003b. The unseen genome: beyond DNA. Sci Am 289: 106-113.

Hakomori S. 2000. Cell adhesion/recognition and signal transduction through glycosphingolipid microdomain. Glycoconj J 17: 143-151.

HAKOMORI S. 2002. Inaugural Article by a Recently Elected Academy Member: Inaugural Article: The glycosynapse Proc Natl Acad Sci USA 99: 225-232.

HaKOMORI S AND HANDA K. 2002. Glycosphingolipiddependent cross-talk between glycosynapses interfacing tumor cells with their host cells: essential basis to define tumor malignancy. FEBS Lett 531: 88-92.

Hakomori S, Handa K, Iwabuchi K, Yamamura S AND PrinetTi A. 1998. New insights in glycosph- 
ingolipid function: "glycosignaling domain', a cell surface assembly of glycosphingolipids with signal transducer molecules, involved in cell adhesion coupled with signaling. Glycobiology 8: xi-xviii.

Handa K, Jacobs F, Longenecker BM and HaKoMORI S. 2001. Association of MUC-1 and PSGL-1 with Low-Density Microdomain in T-Lymphocytes: A Preliminary Note Biochem Biophys Res Commun 285: 788-794.

Hansson GC, Simons K and Van Meer G. 1986. Two strains of the Madin-Darby canine kidney (MDCK) cell line have distinct glycosphingolipid compositions. EMBO J 5: 483-489.

HemLer ME. 2003. Tetraspanin proteins mediate cellular penetration, invasion, and fusion events and define a novel type of membrane microdomain. Annu Rev Cell Dev Biol 19: 397-422.

Hynes RO. 1992. Integrins: versatility, modulation, and signaling in cell adhesion. Cell 69: 11-25.

Ito A, Handa K, Withers DA, Satoh M and HakoMORI S. 2001. Binding specificity of siglec7 to disialogangliosides of renal cell carcinoma: possible role of disialogangliosides in tumor progression. FEBS Lett 498: 116-120.

Iwabuchi K, Yamamura S, Prinetti A, Handa K AND HAKOMORI S. 1998a. GM3-enriched microdomain involved in cell adhesion and signal transduction through carbohydrate-carbohydrate interaction in mouse melanoma B16 cells. J Biol Chem 273: 9130-9138.

Iwabuchi K, Handa K and Hakomori S. 1998b. Separation of "glycosphingolipid signaling domain", from caveolin-containing membrane fraction in mouse melanoma B16 cells and its role in cell adhesion coupled with signaling. J Biol Chem 273: 33766-33773.

JAIN MK AND White HB. 1977. Long-range order in biomembranes. Adv Lipid Res 15: 1-60.

Kannagi R. 1997. Carbohydrate-mediated cell adhesion involved in hematogenous metastasis of cancer. Glycoconj J 14: 577-584.

Kannagi R, Stroup R, Cochran NA, Urdal DL, Young WWJ AND HaKomori S. 1983. Factors affecting expression of glycolipid tumor antigens: influence of ceramide composition and coexisting gly- colipid on the antigenicity of gangliotriaosylceramide in murine lymphoma cells. Cancer Res 43: 4997-5005.

Kingsley DM, Kozarsky KF, Hobbie L and Krieger M. 1986. Reversible defects in O-linked glycosylation and LDL receptor expression in a UDP-Gal/ UDP-GalNAc 4-epimerase deficient mutant. Cell 44: 749-759.

KoJima N and Hakomori S. 1991a. Cell adhesion, spreading and motility of GM3-expressing cells based on glycolipid-glycolipid interaction. J Biol Chem 266: 17552-17558.

Kojima N and Haкомori S. 1991b. Synergistic effect of two cell recognition systems: glycosphingolipidglycosphingolipid interaction and integrin receptor interaction with pericellular matrix protein. Glycobiology 1: 623-630.

Kojima N, Shiota M, Sadahira Y, Handa K AND HAKOMORI S. 1992. Cell adhesion in a dynamic flow system as compared to static system. Glycosphingolipid-glycosphingolipid interaction in the dynamic system predominates over lectin- or integrin-based mechanisms in adhesion of B16 melanoma cells to non-activated endothelial cells. J Biol Chem 267: 17264-17270.

Kojima N, Fenderson BA, Stroud MR, Goldberg RI, Habermann R, Toyokuni T and Hakomori S. 1994. Further studies on cell adhesion based on $\operatorname{Le}(x)-\operatorname{Le}(x)$ interaction, with new approaches: embryoglycan aggregation of F9 teratocarcinoma cells, and adhesion of various tumour cells based on $\mathrm{Le}(\mathrm{x})$ expression. Glycoconj J 11: 238-248.

Krieger M, Reddy P, Kozarsky K, Kingsley D, HobBIE L AND PENMAN M. 1989. Analysis of the synthesis, intracellular sorting, and function of glycoproteins using a mammalian cell mutant with reversible glycosylation defects. Meth Cell Biol 32: 57-84.

Krummel MF AND Davis MM. 2002. Dynamics of the immunological synapse: finding, establishing and solidifying a connection. Curr Opin Immunol 14: 66-74.

Liu P, Ying Y, Ko Y-G AND Anderson RGW. 1996. Localization of platelet-derived growth factorstimulated phosphorylation cascade to caveolae. J Biol Chem 271: 10299-10303. 
Mannion BA, Berditchevski F, Kraeft S-K, Chen LB AND Hemler ME. 1996. Transmembrane-4 superfamily proteins CD81 (TAPA-1), CD82, CD63, and CD53 specifically associated with integrin alpha 4 beta 1 (CD49d/CD29). J Immunol 157: 2039_ 2047.

Matlin KS and Simons K. 1984. Sorting of an apical plasma membrane glycoprotein occurs before it reaches the cell surface in cultured epithelial cells. $\mathbf{J}$ Cell Biol 99: 2131-2139.

Matsuura K, Kitakouji H, Sawada N, Ishida H, Kiso M, Kitajima K and Kobayashi K. 2000. A Quantitative Estimation of Carbohydrate-Carbohydrate Interaction Using Clustered Oligosaccharides of Glycolipid Monolayers and of Artificial Glycoconjugate Polymers by Surface Plasmon Resonance J Am Chem Soc 122: 7406-7407.

McEver RP and Cummings RD. 1997. Perspectives series: cell adhesion in vascular biology. Role of PSGL-1 binding to selectins in leukocyte recruitment. J Clin Invest 100: 485-491.

Menikh A, Nyholm P-G and Boggs JM. 1997. Biochemistry 36 : 3438-3447.

Mineo C, James GL, Smart EJ and Anderson RGW. 1996. J Biol Chem 271: 11930-11935.

Miyake M, Koyama M, Seno M and Ikeyama S. 1991. Identification of the motility-related protein (MRP-1), recognized by monoclonal antibody M3115, which inhibits cell motility. J Exp Med 174: 1347-1354.

Mutoh T, Tokuda A, Miyada T, Hamaguchi M and FuJIKI N. 1995. Ganglioside GM1 binds to the Trk protein and regulates receptor function. Proc Natl Acad Sci USA 92: 5087-5091.

Okada Y, Mugnai G, Bremer EG and Hakomori S. 1984. Glycosphingolipids in detergent-insoluble substrate attachment matrix (DISAM) prepared from substrate attachment material (SAM). Their possible role in regulating cell adhesion. Exp Cell Res 155: $448-456$.

Ono M, Handa K, Withers DA and Hakomori S. 1999. Motility inhibition and apoptosis are induced by metastasis-suppressing gene product CD82 and its analogue CD9, with concurrent glycosylation. Cancer Cancer Res 59: 2335-2339.
Ono M, HANDA K, Withers DA ANd HaKomori S. 2000. Glycosylation effect on membrane domain (GEM) involved in cell adhesion and motility: a preliminary note on functional alpha3, alpha5-CD82 glycosylation complex in ldlD 14 cells. Biochem Biophys Res Commun 279: 744-750.

Ono M, Handa K, Sonnino S, Withers DA, Nagai H AND HAKOMORI S. 2001. GM3 ganglioside inhibits CD9-facilitated haptotactic cell motility: coexpression of GM3 and CD9 is essential in the downregulation of tumor cell motility and malignancy. Biochemistry 40: 6414-6421.

Otsuji E, Park YS, Tashiro K, Kojima N, ToyoKUNI T AND HAKOMORI S. 1995. Inhibition of B16 melanoma metastasis by administration of GM3- or Gg3-liposomes: Blocking adhesion of melanoma cells to endothelial cells (anti-adhesion therapy) via inhibition of GM3-Gg3Cer or GM3-LacCer interaction. Int J Oncol 6: 319-327.

Parton RG and Simons K. 1995. Digging into caveolae. Science 269: 1398-1399.

PASCHER I. 1976. Molecular arrangements in sphingolipids. Conformation and hydrogen bonding of ceramide and their implication on membrane stability and permeability. Biochim Biophys Acta 455: 433-451.

Prinetti A, Iwabuchi K and Hakomori S. 1999. Glycosphingolipid-enriched signaling domain in mouse neuroblastoma Neuro2a cells. Mechanism of ganglioside-dependent neuritogenesis. J Biol Chem 274: 20916-20924

Rahmann H, RöSner H, KÖRTJe K-H, Beitinger H AND VEYBoLd V. 1994. in Biological function of gangliosides (Progress in Brain Research, Vol. 101) (SVENNERHOLM L, Asbury AK, REISFEld RA, SANDHOFF K, Suzuki K, Tettamanti G and Toffano G, eds.), pp. 127-145, Elsevier, Amsterdam.

Rock P, Allietta M, Young WWJ, Thompson TE AND TILlack TW. 1990. Organization of glycosphingolipids in phosphatidylcholine bilayers: use of antibody molecules and Fab fragments as morphologic markers. Biochemistry 29: 8484-8490.

Rock P, Allietta M, Young WWJ, Thompson TE and Tillack TW. 1991. Ganglioside GM1 and asialo-GM1 at low concentration are preferentially 
incorporated into the gel phase in two-component, two-phase phosphatidylcholine bilayers. Biochemistry 30: 19-25.

Ruoslahti E. 1991. Integrins. J Clin Invest 87: 1-5.

SAKAKURA C, IgARASHI Y, ANAND JK, SAdOZAI KK AND HAKOMORI S. 1996. Plasmalopsychosine of human brain mimics the effect of nerve growth factor by activating its receptor kinase and mitogen-activated protein kinase in PC12 cells. Induction of neurite outgrowth and prevention of apoptosis. J Biol Chem 271: 946-952.

Schnaar RL, Collins BE, Wright LP, Kiso M, Tropak MB, Roder JC AND Crocker PR. 1998. in Sphingolipids as signaling modulators in the nervous system (Ann NY Acad Sci, Vol. 845) (LEDEEN RW, HAKomori S, YATES AJ, SchneIder JS AND Yu RK., eds.), pp. 92-105, NY Acad Sci, New York, NY.

Schroeder R, London E ANd Brown D. 1994. Interactions between saturated acyl chains confer detergent resistance on lipids and glycosylphosphatidylinositol (GPI)-anchored proteins: GPI-anchored proteins in liposomes and cells show similar behavior. Proc Natl Acad Sci USA 91: 12130-12134.

Simons K and IKonen E. 1997. Functional rafts in cell membranes. Nature 387: 569-572.

Singer SJ And Nicolson G. 1972. The fluid mosaic model of the structure of cell membranes. Science 185: 720-731.

Sorice M, Parolini I, Sansolini T, Garofalo T, Dolo V, Sargiacomo M, Tai T, Peschle C, Torrisi MR AND Pavan A. 1997. Evidence for the existence of ganglioside-enriched plasma membrane domains in human peripheral lymphocytes. J Lipid Res 38: 969-980.

Steelant WF, Kawakami Y, Ito A, Handa K, BRUYNEel EA, MAREEL M AND HAKOMORI S. 2002. Monosialyl-Gb5 organized with cSrc and FAK in GEM of human breast carcinoma MCF-7 cells defines their invasive properties. FEBS Lett 531: 93-98.

Stefanova I, Horejsi V, Ansotegui IJ, Knapp W and STOCKINGER H. 1991. GPI-anchored cell-surface molecules complexed to protein tyrosine kinases. Science 254: 1016-1019.

Stewart RJ and Boggs JM. 1993. A carbohydrate- carbohydrate interaction between galactosylceramide-containing liposomes and cerebroside sulfatecontaining liposomes: dependence on the glycolipid ceramide composition. Biochemistry 32: 10666 10674.

The C. elegans Sequencing Consortium. 1998. Science 282: 2012-2018.

Tillack TW, Allietta M, Moran RE and Young WWJ. 1983. Localization of globoside and Forssman glycolipids on erythrocyte membranes. Biochim Biophys Acta 733: 15-24.

VArki A. 1994. Selectin ligands. Proc Natl Acad Sci USA 91: 7390-7397.

Venter JC, Adams MD, Myers EW, Li PW, Mural RJ, Sutton GG et AL. 2001. The sequence of the human genome. Science 291: 1304-1351.

Vyas aA, Patel hV, Fromholt Se, Heffer-Lauc M, Vyas KA, Dang J, Schachner M and Schnaar RL. 2002. Gangliosides are functional nerve cell ligands for myelin-associated glycoprotein (MAG), an inhibitor of nerve regeneration. Proc Natl Acad Sci USA 99: 8412-8417.

Watanabe K, Matsubara T and Hakomori S. 1976. alpha-L-Fucopyranosylceramide, a novel glycolipid accumulated in some of the human colon tumors. J Biol Chem 251: 2385-2387.

Yamamura S, Handa K and Hakomori S. 1997. A close association of GM3 with c-Src and Rho in GM3enriched microdomains at the B16 melanoma cell surface membrane: a preliminary note. Biochem Biophys Res Commun 236: 218-222.

Yang LJ-S, Zeller CB, Shaper NL, Kiso M, Hasegawa A, Shapiro RE and Schnaar RL. 1996. Gangliosides are neuronal ligands for myelin-associated glycoprotein Proc Natl Acad Sci USA 93: 814-818.

YATES AJ AND RAMPERSAUd A. 1998. in Sphingolipids as signaling modulators in the nervous system (LEDEEN RW, HAKOMORI S, YATES AJ, SCHNEIDER JS AND YU RK., eds) Vol. 845, pp. 57-71, New York Acad Sci, New York, NY.

Yoshino T, Watanabe K and Hakomori S. 1982. Chemical synthesis of alpha-L-fucopyranosylceramide and its analogues and preparation of antibodies directed to this glycolipid. Biochemistry 21: 928 934. 
Yu S, Withers DA and Hakomori S. 1998. Globoside-dependent adhesion of human embryonal carcinoma cells, based on carbohydrate-carbohydrate interaction, initiates signal transduction and induces enhanced activity of transcription factors AP1 and CREB. J Biol Chem 273: 2517-2525.
Zhu Z, Kojima N, Stroud MR, Hakomori S And FenDERSON BA. 1995. Monoclonal antibody directed to Le(y) oligosaccharide inhibits implantation in the mouse. Biol Repro 52: 903-912. 